\title{
A Política de Educação Integral no Brasil: relações entre poder público e iniciativa privada
}

\author{
Jaqueline C. Camargo \\ Orientadora: Profa. Dra. Débora Cristina Jeffrey
}

\begin{abstract}
Resumo
A educação integral no Brasil enquanto política nacional tem se configurado como uma proposição e iniciativa de caráter pedagógico, que objetiva favorecer a ampliação da jornada escolar, bem como a formação integral de crianças e jovens da educação básica. O marco legal que fundamenta a proposta de educação integral (Portaria Interministerial n. 17 de 24/04/2007 e Decreto n. 7.083 de 27/01/2010) estabelece que o Programa Mais Educação seja reconhecido como uma medida indutora para a adesão de estados, municípios e Distrito Federal à política de educação integral no país. Mediante essa perspectiva, o estudo objetiva identificar e analisar as proposições de educação integral presente na relação estabelecida enquanto política pública com algumas instituições da sociedade civil que orientam a referida política, tendo em vista sua efetividade e melhoria da qualidade de ensino na educação básica.
\end{abstract}

\section{Palavras-chave:}

Educação Integral, Programa Mais Educação, Qualidade de Ensino.

\section{Introdução}

Tendo a política nacional de educação integral como foco da educação básica brasileira legitimada pelo Programa Mais Educação, este trabalho tem o objetivo de verificar e analisar a atuação das Organizações da Sociedade Civil de Interesse Público - OCIP's junto às Secretarias de Educação. A pesquisa organiza-se na observação do funcionamento e das atividades desenvolvidas pelas organizações Fundação Darcy Ribeiro, Educação e Participação e Instituto Ayrton Senna; pautadas no discurso da formação integral do indivíduo para formulação de políticas públicas em educação.

\section{Resultados e Discussão}

A metodologia da pesquisa envolveu o levantamento de dados nos sites das instituições apresentadas em busca de informações-chave como objetivo, orientações, ações, programas e projetos realizados. Identificou-se 0 desenvolvimento de parcerias entre a iniciativa privada com redes públicas de ensino básico - principalmente os Anos Finais do Ensino Fundamental e Ensino Médio através da implementação de projetos diversos em unidades de ensino, voltando-se tanto para o processo de ensino-aprendizagem, como na gestão escolar, formação continuada de professores, currículo pedagógico e suporte às Secretarias de Educação de modo a promover a educação integral para garantir o acesso ao ensino de qualidade. Ao todo, obteve-se dados de 09 projetos, 07 programas e 11 assessorias em andamento - em planos de secretarias estaduais ou municipais de educação.

\section{Conclusões}

A pesquisa possibilita refletir sobre 0 discurso apresentado pelas instituições elencadas que pautam suas ações em grupos socialmente vulneráveis, além de intervirem nas matrizes curriculares e projetos políticos pedagógicos de instituições públicas de ensino, verificando-se a constituição de redes sociais (Mizruchi, 2006) e políticas diante das parceiras público-privadas. Seus projetos suscitam, também, um ideal de educação integral cuja a escola deve se organizar em tempos e currículos próprios- sentidos amplo e restrito (Leclerc e Moll apud Moll, 2012) para a formação integral do sujeito. Tais discussões, fomentadas por tipologias de análises diversas sobre a política de educação integral em tempo integral (Parente, 2016), promovem reflexões e diálogos acerca da formulação, implementação e relações estabelecidas entre os entes federativos e a iniciativa privada uma vez que as referidas instituições embasam suas ações e objetivos na justificativa de que o processo de aprendizagem deve ser para a vida e, não necessariamente, para a escola.

\section{Agradecimentos}

Capes - Procad, Faculdade de Educação/Unicamp, Débora Jeffrey, Maria Aparecida Camargo, José Maria Camargo, Camila Neves, Daniela Caetano, Marta Menezes, Rafahel Parintins, Moisés Silva, Fernanda Carriel, Carlos Caetano.

LECLERC, G. de F. E.; MOLL, J. Programa Mais Educação: avanços e
desafios para uma estratégia indutora da Educação Integral e em tempo integral. Educar em Revista, n. 45, p. 91-110, jul./set. 2012.

MIZRUCHI, Mark S. Análise de redes sociais: avanços recentes e controvérsias atuais. RAE, São Paulo, v. 46, n. 3, p.72-86, jul/dez. 2006.

PARENTE, Cláudia M. D. Construindo uma tipologia das políticas de educação integral em tempo integral. Roteiro, [s.1.], v. 41, n. 3, p.563-586, 4 out. 2016.

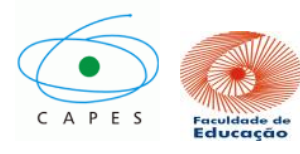

